\title{
Wagyu Beef Aroma in Wagyu (Japanese Black Cattle) Beef Preferred by the Japanese over Imported Beef
}

\author{
Masanori MATSUISHI, Mitsuhiro FUJIMORI and Akihiro OKITANI \\ Faculty of Veterinary and Animal Science, Nippon Veterinary and Animal Science University, \\ Musashino-shi 180-8602, Japan
}

(Received February 23, 2001 ; Accepted August 1, 2001)

\begin{abstract}
Preference of taste or both aroma and taste between Wagyu (Japanese Black Cattle) beef and imported beef on market was compared to reveal reasons why Wagyu beef is considered to be more palatable than imported beef in Japan. Panelists ate heated beef samples and assessed preference on taste by pinching their noses and both aroma and taste by not pinching their noses. As a result there was no difference in preference on taste between both samples, but in the case of both aroma and taste Wagyu beef was significantly preferred to imported beef. Wagyu beef presented a preferable, sweet and fatty aroma, which was different from the conditioned raw beef aroma, while imported beef did not present such an aroma. Therefore, the existence of such an aroma was presumed to be one of the reasons why Japanese people preferred Wagyu beef to imported beef. We proposed to name this aroma Wagyu beef aroma. The optimum cooking temperature to generate Wagyu beef aroma was found to be $80^{\circ} \mathrm{C}$. This aroma was almost absent in Wagyu beef immediately after slaughter. The experiment on additional storage of Wagyu beef slices suggested that a considerable high level of fat-marbling and contact with oxygen were necessary to generate Wagyu beef aroma. On the other hand, an antibacterial agent, chloramphenicol, did not inhibit the generation of Wagyu beef aroma in highly marbled beef stored under air, indicating that a group of bacteria including Brochothrix thermosphacta which is essential for the generation of the conditioned raw beef aroma were not responsible for the generation of Wagyu beef aroma.
\end{abstract}

Animal Science Journal 72 (6) : 498-504, 2001

Key words : Wagyu beef aroma, Conditioned raw beef aroma, Beef conditioning, Meat flavor, Japanese Black Cattle

Japanese people prefer remarkably Wagyu (Japanese Black Cattle) beef to imported beef, Japan Meat Information Service Center conducts a survey of consumer's preference for beef through housewives of 2,000 families across the country every year. On the survey of beef palatability in $1998^{1}, 82.8 \%$ of families answered that Wagyu beef was palatable and only $0.6 \%$ of families answered that it was not palatable. On the other hand, only $3.4 \%$ of families answered that imported beef was palatable and $35.1 \%$ of families answered that it was not palatable. These data indicated that there is a marked difference in either of taste or odor and texture, which constitutes palatability of beef, between Wagyu beef and imported beef. It is well known that Wagyu beef is tender because of high level of marbling. Although imported beef is less tender than Wagyu beef, imported beef is now tender enough for us to enjoy such texture, because it is conditioned for a long period ${ }^{3}$. Therefore, it is unlikely that superiority in tenderness is the only reason why Wagyu beef is considered to be more palatable than imported beef.

It was reported that the desirable aroma named the conditioned raw beef aroma, which is perceived in raw beef, was generated by the conditioning of dairy cattle beef in air and that this aroma could contribute to the

Corresponding : Masanori MATSUISHI (fax : +81 (0) 422-51-6121)

Anim. Sci. J. 72 (6) : 498-504, 2001 
Desirable Aroma of Wagyu Beef

palatability of conditioned beef ${ }^{2)}$. The absence of such aroma was assumed to be one of the reasons for the low palatability of imported beef ${ }^{3)}$. Furthermore, investigation on steak restaurants showed that most Wagyu beef possessed the conditioned raw beef aroma, which appeared to enhance the palatability of the Wagyu beef. Therefore, it was presumed that the conditioned raw beef aroma fairly contributed to the palatability of Wagyu beef, although survey on market Wagyu beef has not been conducted. However, preliminary investigation on market Wagyu beef revealed that a few Wagyu beef possessed the conditioned raw beef aroma, suggesting that the conditioned raw beef aroma does not so much contribute to the palatability of Wagyu beef against our previous presumption. Thus, in this study difference in aroma and taste of heated meats between Wagyu beef and imported beef was examined. Consequently, a desirable aroma different from the conditioned raw beef aroma was observed in Wagyu beef but not in imported beef. We named such an aroma Wagyu beef aroma and investigated conditions for its generation.

\section{Materials and Methods}

\section{Meat samples}

Two kinds of market beef (Japanese Black Cattle (Wagyu) beef and imported beef from U.S.A.) obtained from a retail shop and three kinds of experimentally-conditioned Wagyu beef (beef A, B and C) were used. In Japan, Wagyu beef is used to call the meats of Japanese Black, Japanese Brown, Japanese Shorthorn and Japanese Polled Cattles. About $90 \%$ of Wagyu beef consumed in Japan belongs to the meat of Japanese Black Cattle which produce marbled meat most effectively. Thus, the meat of Japanese Black Cattle as Wagyu beef was used in this study. The breed of the imported beef from USA was not clear but surely differed from the Japanese Black Cattle. Beef marbling grades of market beef were evaluated to be 5 ( the highest grade of Japanese standard) for Wagyu beef and 2 or 3 for imported beef. Periods and conditions for conditioning (aging) of market beef were unknown. Details of the experimentally-conditioned Wagyu beef samples are shown in Table 1. All these samples were obtained
Table 1. Experimentally-conditioned Wagyu beef used in the present study

\begin{tabular}{|c|c|c|c|c|c|}
\hline \multirow{2}{*}{ Beef } & \multirow{2}{*}{$\begin{array}{c}\text { Meat } \\
\text { block } \\
\text { weight } \\
(\mathrm{kg})\end{array}$} & \multirow{2}{*}{ Portion } & \multirow{2}{*}{$\begin{array}{l}\text { Marbling } \\
\text { grade }^{\mathrm{a}}\end{array}$} & \multicolumn{2}{|c|}{$\begin{array}{c}\text { Carcass conditioning } \\
\text { postmortem }^{\mathrm{b}}\end{array}$} \\
\hline & & & & $\begin{array}{c}\text { Temperature } \\
\left({ }^{\circ} \mathrm{C}\right)\end{array}$ & $\begin{array}{r}\text { Period } \\
\text { (days) }\end{array}$ \\
\hline $\mathrm{A}$ & 3.9 & loin & 5 & $0 \sim 4$ & 3 \\
\hline B & 4.2 & loin & 3 & $0 \sim 4$ & 6 \\
\hline $\mathrm{C}$ & 1.2 & loin & 5 & $0 \sim 4$ & 14 \\
\hline
\end{tabular}

a : According to Japanese standard, 5 is the highest grade and 1 is the lowest grade.

$\mathrm{b}:$ All carcasses were conditioned under air.

from livestock experiment stations or wholesale stores.

\section{Organoleptic evaluation}

Trained panelists in our laboratory ate cooked beef samples to evaluate a retronasal aroma ascribable to the odor sensation caused by odorants traveling from the mouth to the nasal cavity via the nasopharyn $\mathrm{x}^{6}$. In some experiments panelists scored the intensity of Wagyu beef aroma by comparison with the standard samples, which were market Wagyu beef slices (their beef marbling grades are 5 ) heated in $1 \% \mathrm{NaCl}$ solution at $80^{\circ} \mathrm{C}$ for $2 \mathrm{~min}$. The scores were as follows : no defined aroma, 0 ; slight or much weaker than the standard, 0.5 ; weaker than the standard, 1.0 ; equal to the standard, 2.0 ; stronger than the standard, 3.0. In almost all experiments, a paired-difference test was employed where the panelists indicated the sample having a stronger Wagyu beef aroma between the two samples prepared under different conditions. Sample indicated by a larger number of panelists having aroma intensity stronger than another sample was decided. This method was used since it revealed more readily and correctly the difference between two samples than the method using the score of aroma intensity.

\section{Results and Discussion}

Wagyu beef aroma as a responsible factor of high preference of Wagyu beef to imported beef in Japan

A paired preference test between Wagyu beef and imported beef using market meats was conducted. Thin-sliced Wagyu beef loins and blocks of imported 
Table 2. Preference test between Wagyu beef and imported beef

\begin{tabular}{|c|c|c|c|c|}
\hline \multirow[t]{2}{*}{ Experiment ${ }^{4}$} & \multirow[t]{2}{*}{ Item } & \multicolumn{2}{|c|}{$\begin{array}{l}\text { Number of panelists } \\
\text { preferring the } \\
\text { indicated sample }\end{array}$} & \multirow{2}{*}{ Difference } \\
\hline & & $\begin{array}{l}\text { Wagyu } \\
\text { beef }\end{array}$ & $\underset{\text { beef }}{\text { Imported }}$ & \\
\hline \multirow[b]{2}{*}{$\mathrm{I}^{\mathrm{c}}$} & Taste & 5 & 3 & NS \\
\hline & $\begin{array}{l}\text { Taste and } \\
\text { odor }\end{array}$ & 8 & 0 & $* *$ \\
\hline \multirow[b]{2}{*}{$\mathrm{II}^{\mathrm{d}}$} & Taste & 6 & 6 & NS \\
\hline & $\begin{array}{l}\text { Taste and } \\
\text { odor }\end{array}$ & 11 & 1 & $* *$ \\
\hline
\end{tabular}

a: Beef samples (ca. $4 \times 3 \times 0.2-0.4 \mathrm{~cm}$ ) were cooked in $1 \% \mathrm{NaCl}$ solution at $80^{\circ} \mathrm{C}$ for $2 \mathrm{~min}$.

$\mathrm{b}$ : Significant difference was indicated with $* *(\mathrm{P}<$ 0.01). NS, not significant.

c : Four panelists joined this preference test. Each panelist cvaluated two pairs of samples.

d: Six panelists joined this preference test. Each panelist evaluated two pairs of samples.

beef loins were purchased in a retail shop. The blocks of imported beef were sliced into $0.2-0.4 \mathrm{~cm}$ in thickness in our laboratory. Trained panelists ate these slices heated in $1 \% \mathrm{NaCl}$ solution at $80^{\circ} \mathrm{C}$ for 2 min and assessed preference on taste by pinching their noses and both aroma and taste by not pinching their noses.

As shown in Table 2, there was no difference in preference on taste between both samples, but in the case of both taste and aroma Wagyu beef was significantly preferable to imported beef. All panelists who preferred aroma and taste of Wagyu beef described that the heated Wagyu beef presented a preferablc, sweet and fatty aroma and that the same aroma could not be detected in heated imported beef. The quality of this aroma was similar but not equal to that (sweet and milk-like) of the conditioned raw beef aroma. Moreover, raw Wagyu beef used in these experiments did not exhibit the conditioned raw beef aroma (data not shown). Therefore, the preferable aroma of heated Wagyu beef was considered to be different from the conditioned raw beef aroma. This result indicated that the good aroma of heated Wagyu beef was the determinant of the preference. Many other experiments were conducted using samples purchased at random from retail shops and presented the same results as experiments I and II (data not shown). Therefore, the name Wagyu beef aroma was proposed for the aroma of heated Wagyu beef, while we called it the conditioned boiled beef aroma in the previous paper ${ }^{5}$. The existence of this aroma as well as the tenderness of Wagyu beef is presumed to be a reason why Japanese people extremely prefer Wagyu beef to imported beef.

In our previous paper $^{2)}$ on the conditioned raw beef aroma, it was supposed that the aroma was left in dairy cattle beef even after cooking, contributing to the superior flavor of conditioned-cooked beef. However, the conditioned raw beef aroma was shown to be easily lost on heating (unpublished data). Therefore, it is likely that Wagyu beef aroma but not the conditioned raw beef aroma would have contributed to the superior flavor of conditioned-cooked beef. The conditioned raw beef aroma might be important in the raw beef cuisine such as tartar steak. When a block or split carcass of beef was conditioned in air but not under vacuum, the conditioned raw beef aroma was demonstrated to generate in the surface part composed of fat and lean meats, because some bacteria such as Brochothrix thermosphacta were involved in its generation ${ }^{5)}$. Therefore, this aroma seems to be a useful indicator to know whether or not a beef block or carcass has been conditioned in air, because the conditioning of beef in air instead of vacuum is suggested to be favorable for the generation of Wagyu beef aroma, as described below.

Optimum cooking temperature for the generation of the Wagyu beef aroma

Patties prepared from market Wagyu beef slices were heated at $40,60,80$ and $100^{\circ} \mathrm{C}$ and compared the intensity of the Wagyu beef aroma to determine the optimum cooking temperature for the generation of this aroma. Meat patties were used instead of sliced meats, so that exactly the same size of samples could be prepared for a uniform heating. As shown in Table 3 , the intensity of this aroma was in the order of : $80^{\circ} \mathrm{C}>60^{\circ} \mathrm{C}>40^{\circ} \mathrm{C}=100^{\circ} \mathrm{C}$. The patties heated in vacuum packs at $100^{\circ} \mathrm{C}$ showed higher scores than 
those heated without vacuum packs at $100^{\circ} \mathrm{C}$ but still lower scores than those heated in vacuum packs at $80^{\circ} \mathrm{C}$, suggesting that the odorants could be lost on

Table 3. Comparison of the strength of the Wagyu beef aroma among Wagyu beef patties heated at 40,60 , 80 or $100^{\circ} \mathrm{C}$

\begin{tabular}{ccccc}
\hline \hline \multirow{2}{*}{$\begin{array}{c}\text { Heating } \\
\text { condition }\end{array}$} & \multicolumn{4}{c}{ Strength of Wagyu beef aroma ${ }^{\circ}$} \\
\cline { 2 - 5 } & $40^{\circ} \mathrm{C}$ & $60^{\circ} \mathrm{C}$ & $80^{\circ} \mathrm{C}$ & $100^{\circ} \mathrm{C}$ \\
\hline & 0.21 & 0.71 & - & - \\
& 0.21 & - & 1.0 & - \\
Unpacked $^{b}$ & 0.21 & - & - & 0.21 \\
& - & 0.57 & 1.1 & - \\
& - & 0.50 & - & 0.07 \\
& - & - & 1.1 & 0.29 \\
\hline Vacuum-packed $^{c}$ & - & - & 1.3 & 0.70 \\
\hline
\end{tabular}

a: Figures mean average scores of the strength of the Wagyu beef aroma evaluated by 7 panelists for paired samples as described in "Materials and Methods".

$\mathrm{b}:$ Meat patties (ca. $3 \mathrm{~cm}$ in diameter and $0.5 \mathrm{~cm}$ in thickness) were prepared after mincing market Wagyu beef (loins) slices. The unpacked meat patty was cooked in $1 \% \mathrm{NaCl}$ solution for $2 \mathrm{~min}$.

c : Meat patties were prepared as mentioned above and vacuum-packed. The vacuum-packed meat patty was cooked in $1 \% \mathrm{NaCl}$ solution for $2 \mathrm{~min}$. heating at $100^{\circ} \mathrm{C}$ because of the vaporization and/or some heat-induced reactions. These results demonstrate that optimum cooking temperature is $80^{\circ} \mathrm{C}$, which is known to be the best cooking temperature of sukiyaki and shabu-shabu served in highly-ranked Japanese restaurants.

\section{Conditions necessary for the generation of Wagyu} beef aroma

Two Wagyu beef loin blocks (beef A and B) within one week postmortem were obtained from two livestock experiment stations and immediately examined their Wagyu beef aroma intensity in comparison with market Wagyu beef slices and imported beef. As shown in Table 4, Wagyu beef aroma of both beef $\mathrm{A}$ conditioned for 3 days postmortem and beef $\mathbf{B}$ conditioned for 6 days postmortem was weaker than that of market Wagyu beef and was as weak as that of imported beef. These results indicate that conditioning for fairly-long periods are necessary to obtain meats rich in Wagyu beef aroma, suggesting that this aroma is almost absent immediately after slaughter.

To determine whether or not the air was necessary to generate Wagyu beef aroma the experiments were conducted using the following conditions. As shown in Table 5, slices and small blocks were prepared from Wagyu beef loin of beef $\mathrm{A}$ and stored under various conditions. In experiment I slices and blocks were stored in $4^{\circ} \mathrm{C}$-air and $-80^{\circ} \mathrm{C}$-air, respectively, up to 11

Table 4. Comparison of Wagyu beef aroma intensity of Wagyu beef conditioned for short periods with market Wagyu beef and imported beef

\begin{tabular}{|c|c|c|c|c|}
\hline \multirow[t]{2}{*}{ Experiment } & \multirow[t]{2}{*}{$\begin{array}{l}\text { Panelist } \\
\text { number }\end{array}$} & \multicolumn{3}{|c|}{$\begin{array}{c}\text { Number of panelists indicating stronger Wagyu beef aroma }{ }^{a} \text { for } \\
\left.\text { (Strength of Wagyu beef aroma }{ }^{b}\right)\end{array}$} \\
\hline & & $\begin{array}{l}\text { Wagyu beef conditioned } \\
\text { for short periods }{ }^{c}\end{array}$ & Market Wagyu beef & Imported beef \\
\hline \multirow{2}{*}{ I } & 3 & $0(0.17)$ & $3(2.0)$ & - \\
\hline & 4 & $2(0.38)$ & - & $2(0.25)$ \\
\hline \multirow{2}{*}{ II } & 7 & $0(0.30)$ & $7(1.3)$ & - \\
\hline & 7 & $4(0.30)$ & - & $3(0.30)$ \\
\hline
\end{tabular}

a : Loin slices $\left(0.2-0.4 \mathrm{~cm}\right.$ in thickness) were cooked in $1 \% \mathrm{NaCl}$ solution at $80^{\circ} \mathrm{C}$ for $2 \mathrm{~min}$.

$\mathrm{b}$ : This shows average scores of the strength of Wagyu beef aroma evaluated by panelists as described in "Materials and Methods".

c : Beef A was used for experiment I and beef B for experiment II. Details of beef A and B were shown in Table 1. 
MATSUISHI, FUJIMORI and OKITANI

Table 5. Wagyu beef aroma of Wagyu beef (beef $\mathrm{A}^{a}$ ) stored additionally in air or vacuum

\begin{tabular}{|c|c|c|c|c|c|c|c|c|c|}
\hline \multirow{3}{*}{$\begin{array}{l}\text { Storage } \\
\text { period } \\
\text { (days) }\end{array}$} & \multicolumn{9}{|c|}{ Number of panelists indicating stronger Wagyu beef aroma ${ }^{b}$ for } \\
\hline & \multicolumn{3}{|c|}{ Experiment I } & \multicolumn{3}{|c|}{ Experiment II } & \multicolumn{3}{|c|}{ Experiment III } \\
\hline & $\begin{array}{l}\text { Slice in } \\
4^{\circ} \mathrm{C} \text {-air }\end{array}$ & $\begin{array}{l}\text { Block in } \\
-80^{\circ} \mathrm{C} \text {-air }\end{array}$ & $\begin{array}{c}\text { No } \\
\text { difference }\end{array}$ & $\begin{array}{l}\text { Slice in } \\
4^{\circ} \mathrm{C} \text {-air }\end{array}$ & $\begin{array}{c}\text { Slice in } \\
4^{\circ} \mathrm{C} \text {-vacuum } \\
\text { e }\end{array}$ & $\begin{array}{c}\text { No } \\
\text { difference }\end{array}$ & $\begin{array}{l}\text { Block in } \\
4^{\circ} \mathrm{C} \text {-airr }\end{array}$ & $\begin{array}{l}\text { Block in } \\
-80^{\circ} \mathrm{C} \text {-air } \\
\end{array}$ & $\begin{array}{c}\text { No } \\
\text { difference }\end{array}$ \\
\hline $1^{\mathrm{g}}$ & 3 & 2 & 0 & 4 & 0 & 0 & 1 & 3 & 0 \\
\hline $5^{\mathrm{h}}$ & 4 & 1 & 0 & 4 & 1 & 0 & 2 & 3 & 0 \\
\hline $11^{\mathrm{i}}$ & 6 & 1 & 0 & - & - & - & - & - & - \\
\hline
\end{tabular}

a : Details of beef $\mathrm{A}$ are shown in Table 1.

b: Loin slices $\left(0.2-0.4 \mathrm{~cm}\right.$ in thickness) were cooked in $1 \% \mathrm{NaCl}$ solution at $80^{\circ} \mathrm{C}$ for $2 \mathrm{~min}$. Trained panelists compared the intensity of the Wagyu beef aroma as described in "Materials and Methods".

c : Loin slices (ca. $4 \times 7 \times 0.2-0.4 \mathrm{~cm}$ ) were stored in $4^{\circ} \mathrm{C}$-air for the indicated periods.

$\mathrm{d}$ : Small loin blocks (ca. $4 \times 7 \times 3.7 \mathrm{~cm}$ ) were stored in $-80^{\circ} \mathrm{C}$-air for the indicated periods. After storage, each block was thawed in tap water and then sliced into $0.2-0.4 \mathrm{~cm}$ in thickness.

e : Loin slices (ca. $4 \times 7 \times 0.2-0.4 \mathrm{~cm}$ ) were vacuum-packed with a nylon/polyethylene film $(50 \mu \mathrm{m}$ in thickness) and then stored at $4^{\circ} \mathrm{C}$ for the indicated periods.

$\mathrm{f}$ : Small loin blocks (ca. $4 \times 7 \times 3.7 \mathrm{~cm}$ ) were stored in $4^{\circ} \mathrm{C}$-air for the indicated periods. After storage, each block was sliced into $0.2-0.4 \mathrm{~cm}$ in thickness.

$\mathrm{g}$ : evaluated by 5 or 4 panelists.

$\mathrm{h}$ : evaluated by 5 panelists.

i : evaluated by 7 panelists.

days. After 5 and 11 days the slices showed a stronger Wagyu beef aroma than the blocks prepared as the blank reference. In experiment II slices were stored in $4^{\circ} \mathrm{C}$-air and in $4^{\circ} \mathrm{C}$-vacuum up to 5 days. After 1 and 5 days the slices in $4^{\circ} \mathrm{C}$-air showed a stronger Wagyu beef aroma than the slices in $4^{\circ} \mathrm{C}$ -vacuum. In experiment III blocks were stored in $4^{\circ} \mathrm{C}$-air and in $-80^{\circ} \mathrm{C}$-air up to 5 days. After 1 and 5 days the blocks in $-80^{\circ} \mathrm{C}$-air showed a stronger Wagyu beef aroma than the blocks in $4^{\circ} \mathrm{C}$-air. These results suggested that contact with oxygen at the unfrozen state was necessary for the generation of Wagyu beef aroma and indicated that slices were more favorable than blocks for its rapid generation.

In order to confirm these results the same experiments as above using beef $\mathrm{C}$ were conducted. As shown in Table 6 , in experiment $I$ the slices in $4^{\circ} \mathrm{C}$-air showed a stronger Wagyu beef aroma than the blocks in $-80^{\circ} \mathrm{C}$-air after 5 days-storage. And in experiment II the slices in $4^{\circ} \mathrm{C}$-air showed a stronger Wagyu beef aroma than the slices in $4^{\circ} \mathrm{C}$-vacuum after 5 days-storage. These results thus confirmed the above- mentioned suggestion that contact with oxygen was necessary for the generation of Wagyu beef aroma.

Moreover, the same experiment as shown in Table 5 using beef $\mathrm{B}$ was conducted and the obtained results are shown in Table 7. In experiment III in Table 7, a similar result was obtained as in experiment III shown in Table 5. However, in experiment $\mathbf{I}$ the slices in $4^{\circ} \mathrm{C}$-air did not show a stronger Wagyu beef aroma than the blocks in $-80^{\circ} \mathrm{C}$-air after 5 days contrary to the result shown in Table 5. Moreover, even in experiment II the slices in $4^{\circ} \mathrm{C}$-air did not show a stronger Wagyu beef aroma than the slices in $4^{\circ} \mathrm{C}$ -vacuum even after 5 days-storage, while for the former two samples (beef $\mathrm{A}$ and $\mathrm{C}$ ) the slices in $4^{\circ} \mathrm{C}$ -air was the most favorable conditions for the aroma generation. The beef marbling grade of beef B was 3 , which was lower than that of beef $A$ and $C$, i.e., 5 . Therefore, these results suggested that a considerably high level of fat-marbling was necessary for the generation of Wagyu beef aroma. 
Desirable Aroma of Wagyu Beef

Table 6. Wagyu beef aroma of Wagyu beef (beef $\mathrm{C}^{\mathrm{a}}$ ) stored additionally in air or vacuum

\begin{tabular}{|c|c|c|c|c|c|c|}
\hline \multirow{3}{*}{$\begin{array}{l}\text { Storage period } \\
\text { (days) }\end{array}$} & \multicolumn{6}{|c|}{ Number of panelists indicating stronger Wagyu beef aroma ${ }^{b}$ for } \\
\hline & \multicolumn{3}{|c|}{ Experiment I } & \multicolumn{3}{|c|}{ Experiment II } \\
\hline & $\begin{array}{l}\text { Slice in } \\
4^{\circ} \mathrm{C} \text {-air }\end{array}$ & $\begin{array}{l}\text { Block in } \\
-80^{\circ} \mathrm{C} \text {-air }\end{array}$ & $\begin{array}{c}\text { No } \\
\text { difference }\end{array}$ & $\begin{array}{l}\text { Slice in } \\
4^{\circ} \mathrm{C} \text {-air }\end{array}$ & $\begin{array}{c}\text { Slice in } \\
4^{\circ} \mathrm{C} \text {-vacuum }\end{array}$ & $\begin{array}{c}\text { No } \\
\text { difference }\end{array}$ \\
\hline $\begin{array}{l}1 \\
5\end{array}$ & $\begin{array}{l}2 \\
5\end{array}$ & $\begin{array}{l}4 \\
2\end{array}$ & $\frac{1}{0}$ & $\begin{array}{l}2 \\
5\end{array}$ & $\begin{array}{l}2 \\
1\end{array}$ & $\begin{array}{l}3 \\
1\end{array}$ \\
\hline
\end{tabular}

a : Details of beef $\mathrm{C}$ are shown in Table 1.

$\mathrm{b}:$ Meat patties (ca. $3 \mathrm{~cm}$ in diameter and $0.5 \mathrm{~cm}$ in thickness) were prepared after mincing loin slices and blocks stored under various conditions, and then cooked in $1 \% \mathrm{NaCl}$ solution at $80^{\circ} \mathrm{C}$ for $2 \mathrm{~min}$. Seven trained panelists compared the intensity of the Wagyu beef aroma as described in "Materials and Methods".

c : Loin slices (ca. $5 \times 7 \times 0.2-0.4 \mathrm{~cm}$ ) were stored in $4^{\circ} \mathrm{C}$-air for the indicated periods.

$\mathrm{d}$ : Small loin blocks (ca. $5 \times 7 \times 4 \mathrm{~cm}$ ) were stored in $-80^{\circ} \mathrm{C}$-air for the indicated periods and thawed in tap water.

e : Loin slices (ca. $5 \times 7 \times 0.2-0.4 \mathrm{~cm}$ ) were vacuum-packed with a nylon/polyethylene film (50 $\mu \mathrm{m}$ in thickness) and then stored at $4^{\circ} \mathrm{C}$ for the indicated periods.

Table 7. Wagyu beef aroma of Wagyu beef (beef $\mathrm{B}^{\mathrm{a}}$ ) stored additionally in air or vacuum

\begin{tabular}{|c|c|c|c|c|c|c|c|c|c|}
\hline \multirow{3}{*}{$\begin{array}{l}\text { Storage } \\
\text { period } \\
\text { (days) }\end{array}$} & \multicolumn{9}{|c|}{ Number of panelists indicating stronger Wagyu beef aroma ${ }^{b}$ for } \\
\hline & \multicolumn{3}{|c|}{ Experiment I } & \multicolumn{3}{|c|}{ Experiment II } & \multicolumn{3}{|c|}{ Experiment III } \\
\hline & $\begin{array}{l}\text { Slice in } \\
4^{\circ} \mathrm{C} \text {-air }\end{array}$ & $\begin{array}{l}\text { Block in } \\
-80^{\circ} \mathrm{C} \text {-air }\end{array}$ & $\begin{array}{c}\text { No } \\
\text { difference }\end{array}$ & $\begin{array}{l}\text { Slice in } \\
4^{\circ} \mathrm{C} \text {-air }\end{array}$ & $\begin{array}{c}\text { Slice in } \\
4^{\circ} \mathrm{C} \text {-vacuum }\end{array}$ & $\begin{array}{c}\text { No } \\
\text { difference }\end{array}$ & $\begin{array}{c}\text { Block in } \\
4^{\circ} \mathrm{C} \text {-air }\end{array}$ & $\begin{array}{l}\text { Block in } \\
-80^{\circ} \mathrm{C} \text {-air }\end{array}$ & $\begin{array}{c}\text { No } \\
\text { difference }\end{array}$ \\
\hline 1 & 1 & 3 & 3 & 1 & 6 & 0 & 2 & 5 & 0 \\
\hline 5 & 1 & 3 & 3 & 3 & 4 & 0 & 1 & 4 & 2 \\
\hline
\end{tabular}

a : Details of beef $\mathbf{B}$ are shown in Table 1 .

$\mathrm{b}$ : Meat patties (ca. $3 \mathrm{~cm}$ in diameter and $0.5 \mathrm{~cm}$ in thickness) were prepared after mincing loin slices and blocks stored under various conditions, and then cooked in $1 \% \mathrm{NaCl}$ solution at $80^{\circ} \mathrm{C}$ for $2 \mathrm{~min}$. Seven trained panelists compared the intensity of the Wagyu beef aroma as described in "Materials and Methods".

c : Loin slices (ca. $2.5 \times 5 \times 0.2-0.4 \mathrm{~cm}$ ) were stored in $4^{\circ} \mathrm{C}$-air for the indicated periods.

$\mathrm{d}$ : Small loin blocks (ca. $2.5 \times 5 \times 3 \mathrm{~cm}$ ) were stored in $-80^{\circ} \mathrm{C}$-air for the indicated periods and thawed in tap water.

e : Loin slices (ca. $2.5 \times 5 \times 0.2-0.4 \mathrm{~cm}$ ) were vacuum-packed with a nylon/polyethylene film ( $50 \mu \mathrm{m}$ in thickness) and then stored at $4^{\circ} \mathrm{C}$ for the indicated periods.

$\mathrm{f}$ : Small loin blocks (ca. $2.5 \times 5 \times 3 \mathrm{~cm}$ ) were stored in $4^{\circ} \mathrm{C}$-air for the indicated periods.

\section{Contribution of bacteria to generation of Wagyu beef aroma}

It was reported that a desirable odor, the conditioned raw beef aroma, was generated by conditioning dairy cattle beef in air and such aroma was presumed to contribute to the palatability of conditioned beef ${ }^{2)}$. Although the conditioned raw beef aroma is perceived when one sniffs raw beef, Wagyu beef aroma is perceived when one eats cooked beef as shown in

Table 3. The conditioned raw beef aroma was 


\section{MATSUISHI, FUJIMORI and OKITANI}

Table 8. Effect of chloramphenicol treatment on generation of Wagyu beef aroma

\begin{tabular}{ccc} 
Experiment $^{a}$ & \multicolumn{2}{c}{ Strength of Wagyu beef aroma } \\
\cline { 2 - 3 } & Control Wagyu beef & Treated Wagyu beef \\
I & 0.9 & 1.2 \\
II & 1.4 & 1.4 \\
\hline
\end{tabular}

a : Five and four panelists evaluated the strength of the Wagyu beef aroma in experiments I and II, respectively.

$b$ : This shows average scores of the strength of the Wagyu beef aroma as described in "Materials and Methods".

c : Market Wagyu beef block was sliced into $0.2-0.4$ $\mathrm{cm}$ in thickness and stored in $4^{\circ} \mathrm{C}$-air for 5 days. After storage the slices were cooked in $1 \% \mathrm{NaCl}$ solution at $80^{\circ} \mathrm{C}$ for $2 \mathrm{~min}$.

$\mathrm{d}$ : Market Wagyu beef block was sliced into $0.2-0.4$ $\mathrm{cm}$ in thickness and soaked in a 200 ppm chloramphenicol solution for $15 \mathrm{sec}$. The slices taken out from the chloramphenicol solution were stored in $4^{\circ} \mathrm{C}$-air for 5 days. After storage the slices were cooked in $1 \% \mathrm{NaCl}$ solution at $80^{\circ} \mathrm{C}$ for $2 \mathrm{~min}$.

assumed to be produced by some kinds of bacteria including Brochothrix thermosphacta at the site containing both leans and fats in the presence of oxygen ${ }^{24}$. The generation of Wagyu beef aroma has been suggested to need oxygen and marbled fat as shown in this study, but contribution of bacteria has been unknown.

In order to clarify whether or not bacteria were responsible for the generation of Wagyu beef aroma, the effect of an antibacterial agent, chloramphenicol, on the generation of the aroma induced by conditioning of highly-marbled beef under air was examined. Chloramphenicol was observed to depress the generation of the conditioned raw beef aroma in our previous paper $^{2)}$. As shown in Table 8, chloramphenicol treatment did not inhibit the generation of Wagyu beef aroma, suggesting that chloramphenicol-sensitive bacteria, including some bacteria producing the conditioned raw beef aroma, are not responsible for the generation of Wagyu beef aroma. Therefore, Wagyu beef aroma is assumed to be generated by the mechanism different from that of the conditioned raw beef aroma.

\section{Acknowledgments}

We are grateful to Mr. Tadaharu Fukuda, Miss. Yoko Uchida, Miss. Yuko Konno and Mr. Yuichi Otsuka for their excellent technical assistance. We thank National Institute of Animal Industry and The Tokyo Metropolitan Livestock Experiment Station for kindly providing Wagyu beef samples. This work was supported in part by a grant-in-aid from The Food Science Institute Foundation (Japan) (Ryoshoku-kenkyukai).

\section{References}

1) Japan Meat Information Service Center. Report on seasonal trends in meat consumption, 39 th examination on consumer in 1998, June. Japan Meat Information Service Center. Tokyo. 1999. (in Japanese).

2) Matsuishi M, Mori J, Moon Y-H, Okitani A. Generation of the desirable aroma, the conditioned raw beef aroma induced by storage of meat in air. Animal Science and Technology, 64 : 163-170. 1993.

3) Matsuishi M, Okitani A. Palatability of beef imported to Japan. Animal Science and Technology, 64 : 171-178. 1993.

4) Matsuishi M, Fujimori M, Moon $Y-H$, Okitani A. Isolation and characterization of a bacterium producing the conditioned raw beef aroma. Animal Science Journal, $71:$ 406-411. 2000.

5) Okitani A. Organoleptic factors responsible for the superior palatability of Japanese Wagyu beef. Pro. ceedings of International Congress of Meat Science and Technology, 45 : 354-359. 1999.

6) Roberts DD, Acree TE. Simulation of retronasal aroma using a modified headspace technique: Investigating the effects of saliva, temperature, shearing, and oil on flavor release. Journal of Agricultural and Food Chemistry, 43 : 2179-2186. 1995. 